$$
2666-3489
$$

\title{
Plant Hormones and their Role in Plant Growth and Development
}

\section{Edited by}

PETER J. DAVIES

Section of Plant Biology

New York State College of Agriculture and Life Sciences

Cornell University, Ithaca, New York, USA 


\section{PLANT HORMONES \\ AND THEIR ROLE IN PLANT GROWTH AND DEVELOPMENT}

\section{Contents}

\section{A. INTRODUCTION}

(1) The plant hormones: Their nature, occurrence, and functions P.J. Davies

(2) The plant hormone concept: Transport, concentration, and sensitivity $-P . J$. Davies

\section{B. HORMONE SYNTHESIS AND METABOLISM}

1 Auxin biosynthesis and metabolism D.M. Reinecke and R.S. Bandurski

2 Gibberellin biosynthesis and metabolism-V.M. Sponsel 43

3 Cytokinin biosynthesis and metabolism-B.A.McGaw 76

4 Biosynthesis and metabolism of ethylene T.A. McKeon and S.F. Yang

5 Abscisic acid biosynthesis and metabolism-D.C. Walton 113

\section{HOW HORMONES WORK}

1 Auxin and cell elongation-R.E. Cleland

2 The control of gene expression by auxin-G. Hagen

3 Gibberellin and abscisic acid in germinating cereals J.V. Jacobsen and P.M. Chandler

4 Hormone binding and its role in hormone action K.R. Libbenga and A.M. Mennes

\section{HORMONE ANALYSIS}

1 Instrumental methods of plant hormone analysis-R. Horgan 222

2 Immunoassay methods of plant hormone analysis V.C. Pence and J.L. Caruso 


\section{E. THE FUNCTIONING OF HORMONES IN PLANT GROWTH AND DEVELOPMENT}

1 Ethylene in plant growth, development, and senescence-M.S. Reid

2 Polyamines as endogenous growth regulators

A.W. Galston and R. Kaur-Sawhney

3 Gibberellins and plant cell elongation-J.P. Métraux

4 The genetic control of growth via hormones-J.B. Reid

5 Auxin transport-P.H.Rubery

6 The induction of vascular tissues by auxin-R. Aloni

7 Hormones and the orientation of growth P.B. Kaufman and I. Song

8 Hormonal regulation of apical dominance-I.A. Tamas

9 Hormones as regulators of water balance-T.A. Mansfield

10 Hormones and reproductive development-J.D. Metzger

11 Hormones and heterosis in plants S.B. Rood and R.P. Pharis

12 The role of hormones in photosynthate partitioning and seed filling-M.L. Brenner

13 The role of hormones during seed development R.S. Quatrano

14 The role of hormones in potato (Solanum tuberosum L.) tuberization-E.E. Ewing

15 The hormonal control of bud and seed dormancy in woody plants-L.E. Powell

16 Hormones in plant senescence-J.J. Goldthwaite

17 Postharvest hormone changes in vegetables and fruit P.M. Ludford

18 Hormones in tissue culture and micropropagation A.D. Krikorian, K. Kelly and D.L. Smith

19 Natural and synthetic growth regulators and their use in horticultural and agronomic crops-T.J. Gianfagna

20 Genes specifying auxin and cytokinin biosynthesis in prokaryotes-R.O. Morris 